\title{
DE DE GRUYTER

\section{The level of the shadow economy, tax evasion and corruption: The empirical evidence for SEE countries}

\section{Rufi Osmani}

Faculty of Business and Economics, South East European University Tetovo,rufi.osmani@seeu.edu.mk

\section{DOI : $10.1515 /$ seeur-2015-0025}

\section{Abstract}

Economic theory and practice of developed countries have shown that the good functioning of market economies requires the existence of stable institutions that are effective in the application of legal rules as a precondition for the proper functioning of the economic and fiscal system.

In the process of building a market economy in Southeast European countries, along with the sector of legal economy there coexists a large sector of shadow economy, tax evasion and high levels of corruption.

Analyses made by many authors and relevant national and international institutions estimate that the amount of the shadow economy, tax evasion and corruption in the analyzed countries despite a declining trend in the last decade continues to be at the level of $25-50 \%$ compared with the legal sector of the economy.

The author aims through a comparative approach to analyze the level of the shadow economy, tax evasion and corruption in the economies of Southeast Europe and provides some recommendations for governments to overcome these negative phenomena.

Key words: economic transition, the informal sector, tax evasion, structural reforms, the Southeast Europe (SEE), UE

JEL Classification: E3, E4, F15, F21, M21. 


\section{Introduction}

During the complex process of transition, in order to achieve macroeconomic stabilization, the governments of the SEE countries with the assistance of the IMF and World Bank implemented reform programme for the transformation and privatization of state enterprises and reformation of the economic system and public institutions.

Political and economic transition in the analyzed countries in the past two decades has been accompanied by many strokes of political, economic and of social nature. These asymmetrical strokes in particular have been significant in countries that won independence from the former Yugoslavia.

After two decades of intensive implementation of economic policies, these countries have achieved macroeconomic stability, but the results in reforming the economy, the public sector and public institutions are insufficient and remain big challenges in the future.

In fact, asymmetric developments during the previous system and low levels of economic growth in the first decade of transition are associated with high levels of unemployment, poverty and a large informal economic sector and fiscal evasion.

These negative phenomena were the main obstacles in the implementation of deep institutional reforms and building of well-functioning market economies in the Western Balkan countries (Osmani, 2014). The process of political and economic transition in the analyzed countries due to asymmetric outcomes has not resolved at an appropriate level three main problems of economic transition (Commander, 1991):

1. Finding the appropriate balance between the public and private sector,

2. Finding the appropriate balance between profits and wages in the private sector, and

3. Finding the appropriate balance between monetary and fiscal policy within the strategy aimed at macroeconomic stabilization and economic development.

Governments of countries in transition through consistent implementation of monetary policy successfully managed the inflation and exchange rates. However, the fiscal policies continue to face numerous challenges that have to do with unjustified growth of public consumption, fiscal deficit and public debt. 
Two of three balances are in sub-optimal levels as a result of numerous deficits and economic and social difficulties. This situation is a consequence of delays in implementing economic and institutional reforms due to the lack of national political consensus and low levels of investments (domestic and foreign) along the process of transition.

In recent years, the professional literature has replaced the concept of "illegal economy" with the concept of "shadow economy" based on the World Bank study done by the authors Friedrich Schneider, Andreas Buehn and Claudio E. Montenegro (Schneider et al, 2010).

Referring to this study, "shadow economy" includes all legal production exposed to the market of goods and services that are deliberately concealed from public authorities for any of the following reasons:

1. To avoid the payment of income, payment of value added tax or other taxes,

2. To avoid the payment of social security contributions,

3. To avoid and not to meet certain legal standards of the labour market, such as minimum wage, maximum working hours, safety standards, etc., and

4. To avoid compliance with certain administrative procedures, such as completing statistical questionnaires or other administrative forms.

Vito Tanzi (1999) competently analyzed the impact of the informal economy and tax evasion in the legal economic sector and public sector. The author states that: "There can be no doubt that the underground economy is a really important phenomenon and its consequences deserve permanent attention and study."

\section{Literature review}

Regarding the shadow economy and fiscal evasion there is a broad literature published by the World Bank, Transparency International and many national and international institutions worldwide.

Despite the broad professional literature for the shadow economy the most serious analysis was made by Friedrich Schneider in his publication "Shadow Economy and work in the shadow: What do we (not) know” (2012). 
In the case of Albania, B.Trebicka analyzed the 1993-2013 period and published the study "The size of Underground Economy in Albania” (2014).

The most comprehensive study about the shadow economy in Bulgaria was published by Harvard University, titled "Shadow Economy in Bulgaria" (2001).

In the case of Croatia the most important analysis for the shadow economy (black economy) is done by M.Svec, "Underground Economy in Croatia" (2009).

In the case of Macedonia, the Centre for Economic Analysis (CEA) has published the study "Shadow economy in Macedonia” (2012).

In Serbia's case the complex study is carried out by the Foundation for the Advancement of Economics, entitled "Shadow economy in Serbia: findings and recommendations for new reforms” (2013).

The author of this study found no specific analyses for the shadow economy in Bosnia and Herzegovina, Kosovo and Montenegro as a part of SEE countries.

Regarding Bosnia and Herzegovina and Kosovo in the study, based on official data published by the World Bank and Transparency International, the author will analyse the consequences of the shadow economy through indicators of corruption, tax evasion and bribery.

I am in the same lines with the broad literature authors consulted in this study, that in all emergency and transition economies the informal economy and tax evasion are integrated parts of the dual economy (legal and illegal economy).

The causes for this situation are assessed to the governments of these countries which did not manifest sufficient political will to fight these negative phenomena and to build effective institutional mechanisms within the national strategies of all included parties (economy, politics, civil sector and other parties).

In the case of Macedonia (Transparency Macedonia, 2013), despite the fact that competent institutions of control and audit have found serious violations of law and misuse of public funds in large amounts, for 20 years of the transitional period a symbolic number of corrupted officials and businessmen have been prosecuted and sentenced, having benefited from the informal economy and tax evasion. 


\section{Research methodology}

The analysis covers the period 2003-2012 and analyzes the following countries: Albania (ALB), Bulgaria (BG), Croatia (CR), Macedonia (MKD), Serbia (SRB), the average of SEE and the average of EU (EU 27). Due to the lack of relevant information from the analysis, we exclude the shadow economy in countries like Montenegro (MNE), Bosnia and Herzegovina (BiH) and Kosovo (KS).

The survey included Croatia and Bulgaria as EU member states in order to compare the results achieved in fighting these negative phenomena with other countries of the SEE that are in the process of integration into the EU as countries that belong to the same geographic region.

Processed information is created using "Mimic" model because there are methodological differences between different methods and results in measuring the shadow economy and fiscal evasion have essential differences. "Mimic" model generally consists of two components that are connected to the variables correlated with unobserved variables applied by the authors (Del'Anno Breusch Giles, Tedds and Schneider).

By using common statistical methods we made a comparative empirical analysis of the level of the shadow economy, tax evasion, corruption and other negative phenomena among the countries of the SEE in relation to the EU countries.

\section{The definition of shadow economy}

The shadow economy (underground economy) according to Feige (1990) and based on the following authors-Tanzi, Smith, Feige, Thomas, Schneider and Bagachwa-is divided into four types:

- Illegal economy - Production and distribution of goods and services forbidden by law such as narcotics, prostitution, smuggling, organized crime, usurious trade and theft.

- Undeclared economy - Activities undertaken with the aim of avoiding established fiscal rules included in tax laws, tax and contribution evasion, and fraud for gain. Cumulative measure of undeclared income is the amount of income which should have been declared to tax authorities but was not. 
- Unregistered (unrecorded) economy - Activities not registered by the official statistics although they should be. This type of economy is measured using income not registered in the System of National Accounts. Unregistered income represents the difference between the total realized income and income registered in the system of accounts.

- Informal economy - Activities which reduce company costs and break administrative rules that regulate property rights, works agreements, credit agreements, and social security system.

The author of this paper refers to Schneider's (2012) definition of the shadow economy as the entity of all market-based legal production activities that are deliberately hidden from public authorities for one or more reasons:

- to avoid payment of income,

- to avoid value added or other taxes,

- to avoid payment of social security contributions,

- to avoid certain legal labour market standards such as minimum wages, maximum working hours, safety standards, etc , and,

- to avoid certain administrative procedures such as completing statistical questionnaires or administrative forms.

In the case of transition countries, Kaufmann and Kaliberda (1996) estimate that the shadow economy has caused a drop in reported GDP, particulary in countries that face major declines in their GDP levels.

The same tendency was recorded in these countries and during the second decade of the transition because the shadow economy continues to be at significant levels.

\section{Vicious cycle of shadow economy}

A huge sector of the shadow economy accompanied with high levels of corruption, tax evasion and other economic and social deformations continues to be a distinctive characteristic of the analyzed economies as a result of a long process of political and economic transition.

The implementation of economic reforms in the early stages of economic transition aimed towards the successful management of three economic issues: 
1) liberalization of prices and trade 2) economic stabilization and 3) economic and structural reforms.

Andrei Shleifer in his analysis in 1996 rightly concluded that price liberalization will eliminate government control over prices, stabilization will impose a policy of tight government budget and privatization will eliminate the direct control of the government over the real sector of the economy. These changes were enough to destroy the economy based on central planning but were not enough to transform the economy into a well-functioning market economy.

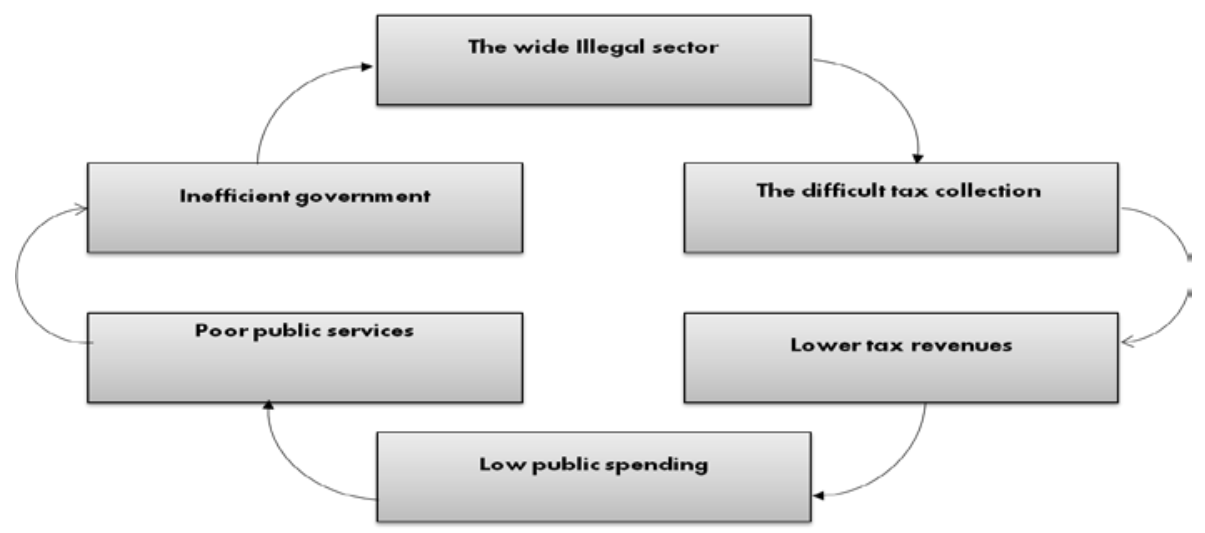

Figure 1.Vicious Cycle (Alesina, 1999).

Many authors argue that the wrong transitional policies produce "the vicious cycle of the economy," which is defined by Alesina (1999) and which converges in a suboptimal balance of the economic sector, the huge shadow economy, weak collection of tax revenues and poor public services presented in figure 1.

In its 2004 report, the Swedish International Development Cooperation Agency Department (SIDA) explained three possible perspectives on the role of government and policy in relation to the shadow economy.

1. Markets function efficiently on their own; government interference would only lead to inefficiency and dysfunction.

2. The informal economy functions outside of government control, largely because those who participate wish to avoid regulation and taxation.

3. The informal economy is enduring; suitable regulation and policies are required. 
The findings of the Swedish agency (SIDA) reflect the situation of the economies of analyzed countries in paragraphs 2 and 3 . The basic problem in the analysed countries relates to the fact that the influences of government in economic markets continue to influence and produce distortions that have encouraged and stimulated the shadow sector of the economy with all negative consequences.

The shadow economy is important in creating jobs and generating income to meet the needs of poor customers offering them cheaper goods and services. Many entities (stakeholders) support government intervention in order to formalize the informal sector and to eliminate the distortions of markets and to increase the collection of taxes.

\section{The Level of Shadow Economy of SEE countries}

The data published by the World Bank, Transparency International and national institutions for the 2003-2012 period evidence the high level of the shadow sector of the economy in all analyzed countries with symbolic improvement trends.

The negative exclusion from the observed trend is Albania, the country where the shadow economy has grown from 33.8\% in 2003 to $42 \%$ in 2012, a double level compared to the EU average (2003-2012). The current government of Albania has undertaken numerous legal activities to legalise the economy and to reduce the shadow economy and tax evasion in all sectors and in particular in the energy sector.

The first results in this direction are encouraging despite the fact that the fight against the shadow economy is accompanied by declining economic activity, increase in unemployment and poverty. These negative consequences are the result of the deep impact of the economic crisis in Greece, the country from which Albania has received large amounts of financial remittances from more than half a million economic migrant workers.

The growth of the shadow economy and tax evasion in the case of Albania based on the analysis of Tribeca (2014) was stimulated by the high level of taxation on income and taxes on additional value (VAT) and especially the fact that many people keep their money out of the legal banking system. 


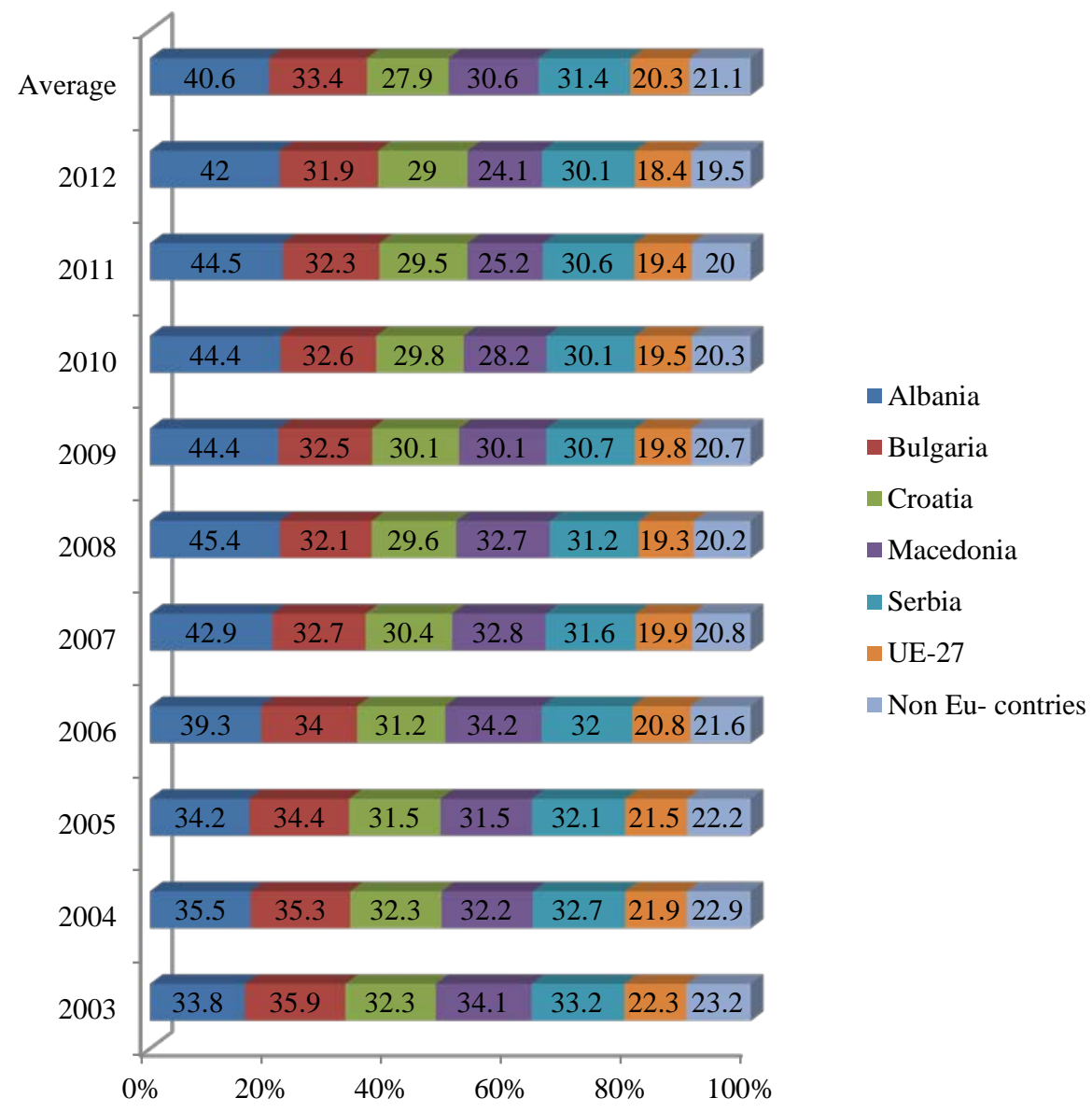

Chart1. The level of shadow economy 2003-2012 (Author's own calculation)

Reducing the shadow economy in the case of Macedonia for $10 \%$ and levelling with EU countries should be accepted with great reserve based on research done by CEA (Garvanlieva, 2012). Research conducted by the Institute of the World Bank and Transparency International (Table 1 of this document) ranks Macedonia at similar levels with other countries of the SEE. The current political and institutional crisis of the present government in Skopje that has ruled the country for a decade can be closely related with the previous statement. 
At the epicentre of the current political and institutional crisis are numerous allegations of senior officials of the central government of Macedonia. Macedonian top officials based on evidence (video records) presented by the opposition have contracted "numerous corrupt agreements" that weigh in individual cases millions of euros of corruption during the realization of public capital investment for the analyzed period.

According to the research conducted by the USAID Business Enabling Project of Serbia, the same trends of the shadow economy in the analyzed period (2003-2012) were noted in Serbia.

The two EU member states from the SEE (Bulgaria and Croatia) have a symbolic reduction of the shadow economy of only 3\% for the period (20032012). The case of Bulgaria and Croatia proves how difficult is the fight against the shadow sector of the economy, if the formal sector of the economy is not in position to achieve higher levels of economic growth as a precondition of reducing unemployment and demotivating economic participation in the informal sector.

The research proves that all analyzed countries during the 2002-2007 period have a positive trend in reducing the shadow economy during the financial crisis: in the 2007-2010 period the trend is negative, while during the last 3 years of analysis (2010-2012) findings are positive in all countries.

These trends are the result of economic recovery after the global economic crisis, in the cases where the official economy begins to recover; people have less incentive to undertake activities within the shadow economy and to gain extra "black" money.

\section{The Cost of Tax Evasion in SEE countries}

Based on the definition of economic activity, the shadow economy is treated as activities that avoid payment of taxes of all kinds. Based on the percentage of the tax burden in the shadow economy we calculated the tax evasion by applying the same percentage of the tax burden on the shadow economy. On the volume of the shadow economy we have calculated the cost of healthcare costs with the aim of defining the total amount of tax evasion and social security evasion. 


\begin{tabular}{|c|c|c|c|c|c|c|c|c|c|}
\hline Country & $\begin{array}{l}\text { GDP } \\
\text { (\$ Mil) }\end{array}$ & $\begin{array}{l}\text { GDP } \\
\text { per } \\
\text { capita } \\
(\$)\end{array}$ & $\begin{array}{c}\text { Size of } \\
\text { shadow } \\
\text { Economy } \\
(\%)\end{array}$ & $\begin{array}{l}\text { Tax } \\
\text { burden } \\
(\%)\end{array}$ & $\begin{array}{c}\text { Govern. } \\
\text { Spending } \\
\text { (\% of } \\
\text { GDP) }\end{array}$ & $\begin{array}{c}\text { Size of } \\
\text { Shadow } \\
\text { economy } \\
(\$)\end{array}$ & $\begin{array}{l}\text { Tax lost } \\
\text { as a } \\
\text { result of } \\
\text { SH.E }\end{array}$ & $\begin{array}{l}\text { Health } \\
\text { Care } \\
\text { spend. } \\
\text { (\$ Mil) }\end{array}$ & $\begin{array}{c}\text { Shadow } \\
\text { Economy } \\
\text { as \% of } \\
\text { HC }\end{array}$ \\
\hline ania & 11,786 & 3,689 & 34.3 & 24.3 & 32.3 & 4,043 & 982 & 801 & 504 \\
\hline lgaria & 47,714 & 6,479 & 35.3 & 33.3 & 37.3 & 16,843 & 5,609 & 3,388 & 497 \\
\hline atia & 60,852 & 14,183 & 32.1 & 23.3 & 40.7 & 19,533 & 4,551 & 4,746 & 412 \\
\hline Macedonia & 9,118 & 4,432 & 37.6 & 28.3 & 34.5 & 3,428 & 970 & 620 & 553 \\
\hline bia & 36,990 & 5,073 & 30.1 & 32.5 & 36.5 & 13,501 & 4,387 & 3,957 & 341 \\
\hline EE aver. & 33,292 & 6,771 & 33.9 & 28.3 & 36.3 & 11,470 & 3,300 & 2,702 & 461 \\
\hline ermany & $3,309,669$ & 40,498 & 16,0 & 40,6 & 43,7 & 529,547 & 214,996 & 347,515 & 152 \\
\hline ance & $2,560,002$ & 38,893 & 15,0 & 44,6 & 52,8 & 384,000 & 171,264 & 286,720 & 134 \\
\hline $\mathrm{K}$ & $2,246,079$ & 36,053 & 12,5 & 38,9 & 47,3 & 280,760 & 109,216 & 195,409 & 144 \\
\hline SA & $14,582,400$ & 46,651 & 8,6 & 26,9 & 38,9 & $1,254,086$ & 337,349 & $2,216,525$ & 56 \\
\hline
\end{tabular}

Tab.1 The Cost of Tax Evasion in SEE and some developed countries of UE in 2010 (Author's own calculation)

Tax evasion as a result of the high level of the shadow economy has a direct impact on fiscal sustainability and financial stability of analyzed countries reducing public funds for current and capital expenditures.

All SEE countries in 2010 have lost fiscal income of 3.3 billion, an amount that is 2.7 times higher compared to the amount of realized FDI of 890 million dollars.

This loss of revenues for public investment exceeded by many times the realized capital investments in these countries in the 2003-2012 period. In the case of Macedonia in 2010, the realized public investment was only 250 million dollars (RM 2010 budget), despite revenue loss of 970 million dollars.

A tax loss in the analyzed countries exceeded several times the public money that has been invested by the governments of these countries for health care of the population; this social service faces a permanent lack of millions of financial funds as a result of the chronic deficit of public funds.

All SEE countries as a result of huge fiscal evasion have evidenced growing fiscal deficits in pension funds and funds of public health, increasing public debt and the increase of total debt. 
In 2010 the overall shadow economy for all SEE countries reached value of 11,470 million dollars, an amount that is $95 \%$ of total budget expenditures, and the amount that is 3. 61 times higher compared to funds invested in the health sector.

The indicators presented in Table 1 argue a huge fiscal gap that exists in the analyzed countries in terms of fighting the shadow economy and tax evasion. The legalisation of the shadow economy within the legal economic activity will stabilize public finances, reduce fiscal costs for businesses and population, and would eliminate irregularities in the labour market and in the markets of goods and services.

Comparison of the data relative to the shadow economy, tax evasion and fiscal cost for analyzed countries in relation to the EU countries and the USA prove the existence of a huge gap, the same findings represented in reports of the European Commission on the progress reports of all countries of SEE to be integrated parts of the EU.

\section{The level of corruption perceptions index in SEE countries}

Rather than paying taxes, entities (companies, individuals) operating in the "shadow economy" protect their positions by paying bribes to government officials who are poorly paid.

With these actions they damage the public finances and the integrity of government, also as consumers (voters) they face the "vicious circle of economy “ phenomenon researched and defined by Alesina (1999).

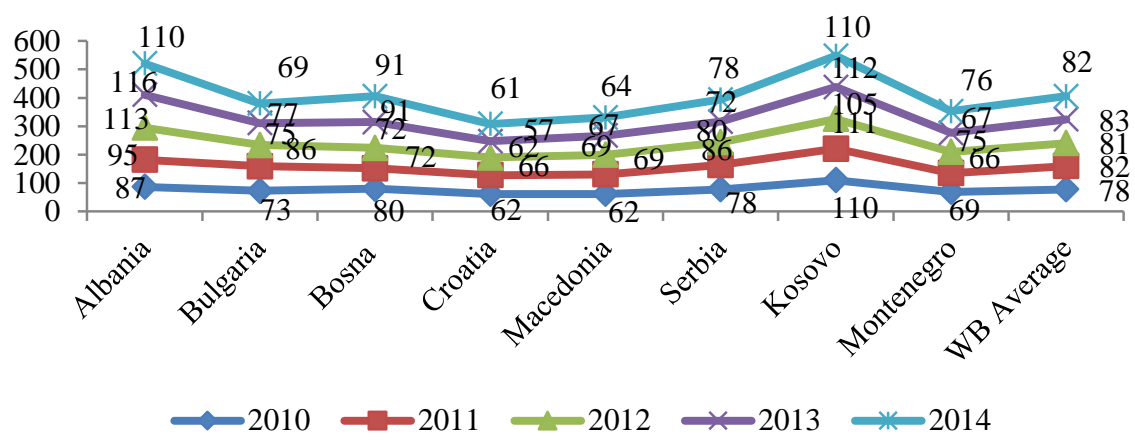

Chart 2. Corruption perceptions index for 2010-2014 (Author's own calculations) 
Companies that are involved in these informal activities benefit from lower costs of salaries and taxes and thereby they create comparative advantages in the markets in relation to legal competition. The data presented in figure 2 prove that the level of corruption observed in the analyzed countries during the (2010-2014) period is very high compared to EU countries.

Albania and Kosovo are listed at the top of this negative list due to the fact that their governments are involved in numerous corruptions and all governments of those states failed in fighting corruption during almost the whole process of transition.

Asymmetrical levels of corruption in some countries (Macedonia, Serbia and Montenegro) on the basis of research conducted by Transparency International for the 2010-2014 period request additional verifications. Researches made by the other institutions for the shadow economy and tax evasion in these countries prove much higher levels of corruption similar to the levels of other countries of SEE.

The author of this paper has real suspicions of the reliability of this data based on the fact that while the level of the informal economy and tax evasion in different countries shows reasonable differences of 5-10\%, in the case of the indicator of Corruption Perceptions there is a discrepancy that exceeds 40$50 \%$.

Based on indicators of Corruption Perceptions presented in the chart 2 the level of corruption in Albania is higher than in Bulgaria for 60\%, while in relation to Serbia it is higher for $41 \%$.

These assessments cannot objectively be accepted as true, because the "Corruption Perception Index" is an indicator derived from the informal economy and tax evasion and in the case of the analyzed countries these negative phenomena are highly correlated at the regional level.

In the case of the indicator the "Corruption Perception Index" there is a substantial exclusion, a fact that makes the results of this research doubtful and not objective. 


\section{Asymmetric level of corruption in various institutions in SEE countries}

The shadow economy, tax evasion and high levels of corruption are a consequence of the fact that public institutions are "captured" from economic entities operating within the informal sector of the economy.

Such a situation is a consequence of payment of huge amounts of bribes from economic entities and citizens to the corrupted officials under the corrupted practices, so-called "managerial tradition of ruling public sector" at all levels of the public sector, as a precondition to realize the formal and informal economic activity.

\begin{tabular}{|c|c|c|c|c|c|c|}
\hline Country & $\begin{array}{c}\text { Political } \\
\text { parties }\end{array}$ & Legislature & Business & Media & $\begin{array}{c}\text { Civil } \\
\text { servants }\end{array}$ & Judiciary \\
\hline $\begin{array}{c}\text { Bosnia \& } \\
\text { Herzegovina }\end{array}$ & 49 & 14 & 9 & 1 & 8 & 14 \\
\hline Bulgaria & 21 & 21 & 5 & 1 & 13 & 38 \\
\hline Croatia & 13 & 9 & 11 & 3 & 20 & 44 \\
\hline Albania & 33 & 12 & 5 & 3 & 11 & 36 \\
\hline Macedonia & 11 & 6 & 7 & 3 & 23 & 50 \\
\hline Serbia & 30 & 14 & 17 & 7 & 17 & 15 \\
\hline Kosovo & 28 & 11 & 11 & 1 & 10 & 39 \\
\hline SEE-average & 26,5 & 12,5 & 9 & 2,7 & 14,5 & 35 \\
\hline UE-average & 32 & 11 & 23 & 9 & 18 & 9 \\
\hline
\end{tabular}

Tab. 2 Which institutions are the most affected by corruption of SEE in 2010 (Author's own calculation)

The data presented in Table 2 prove the perception that the judiciary, political parties and civil service sectors are the most corrupted entities within all analyzed countries.

The data presented in Table 2 are the most powerful proof of why all governments of SEE countries without any exception have no relevant results in fighting the negative phenomena of the shadow economy, tax evasion and corruption.

\section{Conclusions and recommendations}

- The countries of Southeast Europe, after two decades of economical and political transition, continue to face a huge shadow economy, tax 
evasion, corruption and other negative consequences as a result of the prolonged economic transition;

- Under the process of fulfilling the criteria of Maastricht and Copenhagen as preconditions of integration in the EU in the second decade of transition, countries of SEE have achieved macroeconomic stabilization but failed in achieving appropriate levels of economic growth and, as a consequence, they face very high levels of poverty, unemployment and social difficulties;

- The trends of the shadow economy, tax evasion and corruption of officials have the tendency of decreasing, but only by 2-5\% in the 20022012 period. Only in the case of Albania is the tendency of shadow economy, tax evasion and corruption permanently increasing, despite the fact that the current government of Albania seriously fights institutionally the shadow economy and tax evasion;

- In the case of SEE countries the phenomenon of the shadow economy is not the result of huge fiscal burdens but of ineffective and selective implementation of tax laws and government regulations that create favourable preconditions for the development of the shadow economy, and of tax evasion associated with high levels of institutional corruption;

- A faster integration of SEE countries into NATO and the quality fulfilment of the criteria of Copenhagen in the process of integration into the EU are substantial prerequisites for improving the institutional reforms as preconditions of successfully fighting the shadow economy, tax evasion and corruption;

- Fighting the shadow sector of the economy, tax evasion and corruption should be implemented and practiced as a joint responsibility of government, the legal economic sector, nongovernment and civil organizations and the population. Only a functional coordination between all parties within a national strategy can provide positive results in fighting these negative phenomena in the long run;

- The high level of the shadow economy, tax evasion and corruption is the result of a low cultural level and civilization of the SEE countries that find answers in the well- known declaration of the great German economist Joseph Schumpeter: "The soul of a people, its cultural level, its social structure, which jobs its policy may offer, all those are recorded in its tax history. Who knows how to listen to these messages will know how to hear the cries of world history more clearly than from any other source'”. 


\section{References}

- Friedrich Schneider (2012) "The Shadow Economy and, Work in the Shadow: What Do We (Not) Know”, Johannes Kepler University of Linz and IZA, Bonn, Germany,

- Schneider, F., (2000) "Illegal activities, but still value added: Size, causes and measurement of the shadow economies all over the world”. Working Paper, No. 305,

- Feige, E. L., (1990) “Defining and estimating underground and informal economies: The new institutional economics approach”. World Development,

- S.Commander (Ed) (1991) "Managing Inflation in Socialist Economies in Transition, Economic Devolopment Institute”, The World Bank Washington,

- S.Kely,A.Werner ,L.Dimtrov,Krustev ,Aleksandrova,Stanchev(2001) “The Shadow economy in Bulgaria”, Sofia ,

- Tanzi, V. (1999). "Uses and abuses of estimates of the underground economy”, The Economic Journal 109 /456,

- B.Trebica (2014) "The Size of Underground Economy in Albania", Academic Journal of Interdisciplinary Studies, MCSER Publishing, RomeItaly ,

- CEA ,Garvanlieva, Ivanov,Nikolov (2012) "The Shadow economy in Macedonia”, Skopje ,

- USAID Business Enabling Project (2013) “The Shadow Economy in Serbia ,New Findings and Recommendations for Reform”Belgrade ,

- Vjekoslav Klarić, (2010) "Estimating The Size Of Non-Observed Economy In Croatia Using The Mimic Approach”, Financial Theory and practice ,

- M. Švec,(2009)”Underground Economy in Croatia”, Financial Theory and Practice ,

- Andrews, D., A. Caldera Sánchez and Å. Johansson (2011). “Towards a Better Understanding of the Informal Economy”, OECD Economics Department Working, Papers, No. 873, OECD, 
- The IMF (2000-2013), The annual report for: Albania, Bulgaria, Croatia, FYR of Macedonia, Serbia, Kosovo. Bosnia and Herzegovina, Montenegro

- Roberto Dell'anno,(2007)’The Shadow Economy In Portugal: An Analysis With The Mimic Approach”, Journal of Applied Economics. Vol X, No. 2,

- Fleming et al., (2000), “The Shadow Economy”, Journal of International Affairs, The Trustees of Columbia University in the City of New York,

- Ali M. El-Agraa (2011) "The European Union: Economics and Policies", $9^{\text {th }}$ edition, Cambridge University Press (2011),

- Baldwin \&Richard (2012) “Economics of European Integration”, $4^{\text {th }}$ revised edition, McGraw-Hill Higher Education,

- Hermann J.Blanke, Stelio Mangiameli (2013). "The Treaty on European Union (TEU): A Commentary”, Springer.

- Osman \&Mazllami(2008)“The fulfillment of the Maastricht and Copenhagen criteria: A serious challenge for Macedonia toward EU”, Journal of Faculty of Economy, University of Tirana.

- Osmani\& Deari (2009) "Economic Transition and the effects of tax reform on FDI: The Case of FYROM", Scientific Journal for economic and social issues Universum University - IRC, Prishtina.

- Thomas Christiansen, Simon Duke (2013):"The Maastricht Treaty: Second Thoughts after 20 Years”, Routledge,

- McKinsey Global Institute. (2010), "Incentives and Investments: Evidence and Policy Implications.” FIAS, World Bank Group, Washington, DC.

- The Cost of Tax Abuse (2011) "A briefing paper on the cost of tax evasion worldwide”, The Tax Justice Network.

- Annual report (2000- 2012), Transparency International, Global Corruption Barometer. 